\title{
Differences in serum markers of oxidative stress in well controlled and poorly controlled asthma in Sri Lankan children: a pilot study
}

Yenuli Fernando ${ }^{1,2}$, Pujitha Wickramasinghe ${ }^{3}$, Udani De Silva', Malintha Alahakoon ${ }^{4}$, K. W. D. A. Anuradha ${ }^{3}$ and Shiroma Handunnetti ${ }^{*}$

\begin{abstract}
Background: Asthma is a disease characterised by hyper responsiveness and bronchoconstriction of airways, and is a major health burden globally. A dysfunction of the oxidant-antioxidant balance, termed oxidative stress, has been implicated in the pathophysiology of asthma. The present study aims to assess the changes in oxidative stress markers, namely nitric oxide metabolites and antioxidant capacity, in children with poorly controlled and well controlled asthma, in comparison to healthy controls.
\end{abstract}

Methods: The present study enrolled 72 children (ages 5-15 years) classified into three groups: (1) poorly controlled asthma $(n=20)$, (2) well controlled asthma $(n=24)$ and (3) healthy controls $(n=27)$. An interviewer-administered questionnaire was used to record socio-demographic data of the participants. The serum concentrations of the oxidant markers (nitrite, nitrate and total nitric oxide metabolites [NO $\left[\mathrm{NO}_{x}\right.$ ) were determined using the Griess test, and the total antioxidant capacity (TAOC) was determined using the ABTS decolorisation method. The concentrations of these markers were compared across the three groups.

Results: The three study groups were similar in terms of socio-demographic data. The differences across the three groups were statistically significant for serum concentrations of nitrate and $\mathrm{NO}_{x}$ (but not nitrite) and serum TAOC. Further analyses showed that the disparity for nitrate and $\mathrm{NO}_{x}$ concentrations was greatest between poorly controlled asthma and healthy controls $(p=0.001$ and $p<0.001)$ compared to the well-controlled asthmatics and healthy controls ( $p=0.036$ and $p=0.049$ ). A significant difference in serum nitrate and $\mathrm{NO}_{x}$ concentrations was not observed between the two asthma groups $(p=0.311$ and 0.203$)$. The TAOC were significantly lower in poorly controlled asthmatics as compared to well-controlled asthmatics $(p=0.003)$ and healthy controls $(p<0.001)$. However, there was no significant difference in the serum TAOC between healthy controls and well-controlled asthmatics $(p=0.496)$. These findings may indicate that it is perhaps the higher TAOC that contributes to the well controlled state of asthma. Conclusions: The present study indicated that an imbalance of oxidants and antioxidants in the serum may have an underlying role in asthma pathophysiology, and how these markers may be effective in asthma management.

Keywords: Childhood asthma, Oxidative stress, Nitric oxide, Antioxidants

*Correspondence: shiromah@ibmbb.cmb.ac.lk

${ }^{1}$ Institute of Biochemistry, Molecular Biology and Biotechnology, University of Colombo, Colombo, Sri Lanka

Full list of author information is available at the end of the article

\section{Background}

Asthma is a disease characterised by airway hyperresponsiveness, airway remodelling and reversible bronchoconstriction, affecting an estimated 235 million individuals worldwide, with a mortality of 383,000 deaths annually $[1,2]$. The prevalence of asthma is rising 
in Sri Lanka where it occurs in 13-25\% of children aged between 5 and 11 years, and is a major cause for school absenteeism in addition to being an economical burden in healthcare [3]. In 2015 alone, the Sri Lankan government allocated LKR 140 million (approximately 1 million CAD) for asthma treatment [4].

The full scope of molecular mechanisms underpinning the changes seen in asthma is still unclear. Plausible contributory mechanisms include genetic predisposition [5-9], epigenetic alterations $[10,11]$, exposure to environmental pollutants [12, 13], chemicals [14] and viral infections [15] acting as triggers of inflammation.

Recently, there has been an interest in the role of oxidant-antioxidant balance (oxidative stress) in the pathophysiology of asthma. Oxidative stress arises from an imbalance between the production of reactive oxygen species (ROS) and reactive nitrogen species (RNS) accompanied by a depletion of the antioxidant defense mechanisms [16]. RNS may be generated by the reactions of nitrite and nitric oxide (NO) with ROS [17]. The elevated production of $\mathrm{NO}$, or 'nitrosative stress', may aggravate the detrimental effects of airway inflammation. Nitrite $\left(\mathrm{NO}_{2}{ }^{-}\right)$and nitrate $\left(\mathrm{NO}_{3}{ }^{-}\right)$are metabolites of $\mathrm{NO}$ oxidation by the superoxide anion, and serve as proxy measures of the unstable ROS [18]. Antioxidants include non-enzymatic molecules (glutathione, albumin, uric acid, bilirubin, vitamins $\mathrm{A}, \mathrm{C}$, and $\mathrm{E}$, and several molecules/chemicals present in foods), and enzymatic systems such as superoxide dismutase (SOD), catalase and glutathione peroxidase [19]. Increased amounts of ROS and RNS in the blood diminish antioxidant capacity [20]. Oxidative stress has been implicated in many pathological conditions, including asthma [2126]. As the severity of illness increases, antioxidants are depleted to a greater extent [27]. The persistent and intermittently exacerbated inflammation is accompanied by overproduction of ROS and RNS, which may also contribute to the promotion and persistence of the airway inflammation in asthma [23].

This pilot study aims to determine the markers of oxidative stress in children with poorly controlled (symptomatic) and well controlled asthma (asymptomatic) patients in comparison to an age-sex matched group of healthy controls, in order to determine if greater oxidative stress does occur in uncontrolled asthma. This could highlight the potential use of oxidative stress measurement as an indicator of disease severity and a plausible role of antioxidants in asthma management.

\section{Methods}

\section{Clinical study design, sample size and data collection}

This comparative study was carried out from June to October 2019, amongst children aged 5-15 years presenting to the outpatient clinic of the University Paediatric Unit of the Lady Ridgeway Children's Hospital, which is the premier, tertiary level paediatric hospital in Sri Lanka. Three groups of children were enrolled: (1) poor asthma control while on corticosteroid/combined inhalers (according to Global Initiative for Asthma [GINA] criteria) $(n=20)$ (Table 1$)$, (2) well controlled asthma for the past 12 months while on regular inhaled corticosteroid treatment (according to GINA criteria) $(\mathrm{n}=24)$ and (3) age-sex matched healthy controls $(\mathrm{n}=27)$.

The control group did not have any acute or chronic illness requiring long-term medications, atopic diseases or any symptoms of obstructive airway disease. Their peak expiratory flow rates were within the normal ranges for the age, height and sex. Age-sex matched children were recruited to all three groups when possible. Children with another comorbidity that can mimic asthma (e.g. congenital heart diseases, gastrooesophageal reflux disease) as well as those without parental consent were excluded.

There have been no previous studies that had measured oxidative stress in asthma in Sri Lanka. Hence the sample size was calculated based on an analogous study that assessed oxidative stress in fever patients in Sri Lanka using the same assays [28]. The mean difference and standard deviations of nitric oxide metabolites between healthy controls and fever patients in the aforementioned

Table 1 GINA assessment of asthma control in children 6-15 years and adolescents

\begin{tabular}{llll}
\hline Symptom control & Level of asthma symptom control & \\
\hline In the past 4 weeks has the patient had & & Well controlled & Partly controlled \\
Day symptoms more than twice a week & Y/N & None of these & 1 to 2 of these \\
Any night waking due to asthma & Y/N & \\
Relievers needed more than twice a week & Y/N & \\
Any activity limitation due to asthma & Y/N & \\
\hline
\end{tabular}

(Pocket guide for asthma management and prevention, GINA 2019) 
study was used as guidance to estimate sample size with a power of $80 \%$ and a $95 \%$ confidence interval for this study, which indicated that the sample size should at least be 20 per group. A convenient sampling technique with case matching was used.

An interviewer-administered questionnaire was used to record socio-demographic data (including monthly family income and parents level of education), and to clarify the degree of asthma control focussing on the GINA criteria. A general health check up was carried out for all children after consenting to participate. A stool smear examination, Full Blood Count and ESR was done free of charge. No parasites or parasitic stages were found on examination of saline and iodine smears. There was no significant difference in the ESR levels between the asthmatic children and healthy children.

\section{Sample collection, transport and storage}

Trained experienced nurses in the clinic collected blood under aseptic conditions. Since serum nitrate is dependent on dietary factors [29-32], blood samples were collected $8 \mathrm{~h}$ after the last meal in the morning. $3 \mathrm{ml}$ of blood was put into a sterile plain tube and allowed to clot for $15 \mathrm{~min}$ at room temperature prior to centrifugation at $2000 \mathrm{rpm}$ for 15 minutes [33]. Serum was separated and stored at $-20{ }^{\circ} \mathrm{C}$ until analysis was carried out for estimation of oxidative stress markers.

\section{Assays to determine the nitrite, nitrate and $\mathrm{NO}_{\mathrm{x}}$ concentrations and antioxidant capacity}

All laboratory tests were carried according to previously published protocols [34, 35].

In brief, the Griess reaction was used to determine the concentrations of nitrite and total nitric oxide metabolites $\left(\mathrm{NO}_{\mathrm{x}}\right.$ denoting $\mathrm{NO}_{2}{ }^{-}$and $\left.\mathrm{NO}_{3}{ }^{-}\right)$in test sera. The sera were deproteinised chemically by adding $1.5 \mathrm{~g} / \mathrm{ml}$ zinc sulfate and mixing for $1 \mathrm{~min}$ (by vortex). The mixtures were centrifuged at $10000 \mathrm{~g}$ for $15 \mathrm{~min}$, and the supernatant was separated and centrifuged at $10000 \mathrm{~g}$ for $10 \mathrm{~min}$. The serum nitrite concentration was analysed by mixing $100 \mu \mathrm{l}$ of deproteinised serum and $100 \mu \mathrm{l}$ of Griess reagent (prepared as a 1:1 mixture of $1 \%$ sulphanilamide in 5\% phosphoric acid and $0.1 \%$ $\mathrm{N}$-(1-naphytyl) ethylenediamine hydrochloride) followed by an incubation of $15 \mathrm{~min}$ in dark at room temperature. The serum $\mathrm{NO}_{\mathrm{x}}$ concentration was analysed by mixing $70 \mu \mathrm{l}$ of deproteinised serum, $70 \mu \mathrm{l}$ of $8 \mathrm{mg} / \mathrm{ml}$ vanadium (III) chloride and $70 \mu \mathrm{l}$ of Griess reagent, followed by an incubation of $30 \mathrm{~min}$ at room temperature in dark.

The absorbance was measured using a spectrophotometer (Synergy HT multimode microplate reader, Biotek, USA) at $540 \mathrm{~nm}$ in 96 -well microplates in duplicates alongside series of sodium nitrite twofold dilutions $(100 \mu \mathrm{M}-0.195 \mu \mathrm{M})$ and reagent blanks. The concentrations of nitrite and $\mathrm{NO}_{\mathrm{x}}$ in sera were calculated using a standard curve made from serial dilutions. As the serum $\mathrm{NO}_{\mathrm{x}}$ represents nitrite and nitrate in serum, the serum nitrate concentration was determined according to Fitzpatrick et al. by deducting the serum nitrite concentration from the serum $\mathrm{NO}_{\mathrm{x}}$ concentration [18].

The total antioxidant capacity (TAOC) of test sera was analyzed using the 2,2'-azinobis-(3ethylbenzothiazoline-6-sulfonic acid) (ABTS) decolourisation method. To facilitate the formation of radical cations $\left(\mathrm{ABTS}^{+}{ }^{+}\right.$) by oxidation, $7 \mathrm{mM}$ ABTS solution and $2.4 \mathrm{mM}$ potassium persulphate $\left(\mathrm{K}_{2} \mathrm{~S}_{2} \mathrm{O}_{8}\right)$ were mixed in equal volumes and maintained in dark for $5 \mathrm{~h}$. The ABTS working solution was prepared by diluting the mixture with $5 \mathrm{mM}$ phosphate/0.145 M $\mathrm{NaCl} \mathrm{pH} 7.4$ phosphate buffered saline (PBS) according to the dilution factor which produces an optical density of $\approx 0.400$ at $734 \mathrm{~nm}$ (determined using an ABTS:PBS dilution series). The test sera were analyzed in 96-well microplates in duplicates alongside a series of 6-Hydroxy-2,5,7,8-tetramethyl-chroman-2-carboxylic acid (Trolox) two-fold dilutions (400 $\mu \mathrm{M}-5 \mu \mathrm{M})$, reagent blanks (a mixture of $10 \mu \mathrm{l}$ of distilled water, $10 \mu \mathrm{l}$ of $\mathrm{K}_{2} \mathrm{~S}_{2} \mathrm{O}_{8}$ and the volume of PBS that is the product of $20 \mu \mathrm{l}$ and the ABTS:PBS dilution factor) and controls (a 1:19 mixture of PBS and working ABTS solution).

Test sera were mixed with ABTS working solution in a 1:19 ratio within a minute in dark. The absorbance at $734 \mathrm{~nm}$ was determined using a spectrophotometer (Synergy HT multimode microplate reader, Biotek, USA) at $734 \mathrm{~nm}$. The Trolox standard curve was used to determine the serum TAOC as expressed as a Trolox equivalent antioxidant capacity (TEAC).

\section{Data analysis}

The data were transferred into a Microsoft Excel database and checked for accuracy. The analysis was done using Statistical Package for the Social Sciences/ Statistical Product and Service Solutions (SPSS) version 23.0 (IBM, USA). Descriptive statistics were summarised with measures of central tendency and measures of dispersion. Discrete variables across study groups were compared with Chi square test. The laboratory assay results were arranged into data arrays, tested for normal distribution and differences across groups were tested with the Kruskal-Wallis test, Mann-Whitney U test and Spearman's correlation 
as appropriate. A p value $<0.05$ was considered as statistically significant.

\section{Results}

\section{Characteristics of the study population}

A total of 72 children were enrolled in the study; 20 children with poorly controlled asthma, 25 children with well controlled asthma and 27 healthy children.

When the baseline socio-demographic characteristics in the three groups of children were considered, there was a similar age and gender distribution across all three groups. The mean age (expressed as mean \pm standard deviation in years) of children with well controlled asthma, poorly controlled asthma and controls was $8.96 \pm 2.58, \quad 8.80 \pm 2.52$ and $9.97 \pm 2.82$, respectively. There were no significant differences in the sociodemographic characteristics, namely mother's and father's education and monthly family income between the three groups $(p>0.05)$. Considering differences in co-morbidities between poorly and well controlled asthmatic children, except for higher number of allergic rhinitis in former, there were no significant difference in food or drug allergy, eczema or obesity.

\section{Markers of oxidative stress across the study groups}

The mean serum nitrite, nitrate and $\mathrm{NO}_{\mathrm{x}}$ concentrations were highest in the poorly controlled asthma group and lowest in the healthy controls. The mean serum nitrite, nitrate and $\mathrm{NO}_{\mathrm{x}}$ concentrations in the well-controlled asthma group was lower than in the poorly controlled asthma group, but higher than the healthy controls. In contrast, the highest mean serum TAOC was observed in the healthy controls group while the lowest mean serum TAOC was observed in the poorly controlled asthma group (Table 2).

When the medians were considered, there were significant differences across the study groups with regard to serum nitrate and $\mathrm{NO}_{\mathrm{x}}$ concentrations (but not nitrite concentrations) and serum TAOC (Table 3 and Fig. 1).

Further analysis of significant variables across the groups using the Mann-Whitney $U$ Test showed that the disparity between groups for nitrate and $\mathrm{NO}_{\mathrm{x}}$ concentrations was greatest between the poorly controlled asthma and healthy controls groups $(p=0.001$ and $p<0.001$ respectively) compared to the well-controlled asthma and healthy controls groups $(\mathrm{p}=0.036$ and $\mathrm{p}=0.049$ respectively). There were no significant differences in these parameters between the well-controlled asthma and the poorly controlled asthma groups ( $\mathrm{p}=0.311$ and 0.203 respectively). The MannWhitney U Test analyses showed that the serum TAOCs were significantly different across the two asthma groups $(p=0.003)$ and across the poorly controlled asthma group and healthy controls $(\mathrm{p}<0.001)$. There was no statistically significant difference between the well-controlled asthma and healthy controls groups $(\mathrm{p}=0.496)$ (Table 4$)$.

\section{Correlation of oxidants and antioxidant capacity}

The serum TAOCs of the study population were correlated with the respective serum nitrite, nitrate and $\mathrm{NO}_{\mathrm{x}}$ concentrations in order to determine how

Table 2 Comparison of mean ( \pm standard deviation) of test parameters between the study groups

\begin{tabular}{lccc}
\hline & $\begin{array}{l}\text { Poorly controlled asthma } \\
(\mathbf{n = 2 0 )}\end{array}$ & $\begin{array}{l}\text { Well controlled asthma } \\
(\mathbf{n = 2 4 )}\end{array}$ & Healthy controls $(\mathbf{n}=\mathbf{2 7})$ \\
\hline Serum nitrite concentration $(\mu \mathrm{M})$ & $0.36 \pm 0.65$ & $0.17 \pm 0.20$ & $0.13 \pm 0.18$ \\
Serum nitrate concentration $(\mu \mathrm{M})$ & $5.02 \pm 2.02$ & $4.46 \pm 2.12$ & $3.19 \pm 1.16$ \\
Serum $\mathrm{NO}_{x}$ concentration $(\mu \mathrm{M})^{\mathrm{a}}$ & $5.37 \pm 2.12$ & $4.63 \pm 2.19$ & $3.32 \pm 1.21$ \\
Serum TAOC $(\mu \mathrm{M})$ & $336.40 \pm 20.38$ & $359.33 \pm 25.46$ & $367.12 \pm 12.45$ \\
\hline
\end{tabular}

${ }^{a} \mathrm{NO}_{x}$ denotes $\mathrm{NO}_{2}{ }^{-}$and $\mathrm{NO}_{3}{ }^{-}$collectively

Table 3 Comparison of medians ( \pm interquartile range) of test parameters between the study groups

\begin{tabular}{|c|c|c|c|c|}
\hline & $\begin{array}{l}\text { Poorly controlled asthma } \\
(n=20)\end{array}$ & $\begin{array}{l}\text { Well controlled asthma } \\
(n=24)\end{array}$ & Healthy controls $(n=27)$ & $p$ value \\
\hline Serum nitrite concentration $(\mu \mathrm{M})$ & $0.14 \pm 0.37$ & $0.12 \pm 0.26$ & $0 \pm 0.23$ & 0.149 \\
\hline Serum nitrate concentration $(\mu \mathrm{M})$ & $4.79 \pm 2.15$ & $3.93 \pm 3.28$ & $3.34 \pm 2.15$ & $0.003^{*}$ \\
\hline Serum $\mathrm{NO}_{\mathrm{x}}$ concentration $(\mu \mathrm{M})^{\mathrm{a}}$ & $5.06 \pm 2.31$ & $4.05 \pm 3.32$ & $3.53 \pm 2.35$ & $0.003^{*}$ \\
\hline Serum TAOC ( $\mu \mathrm{M})$ & $333.20 \pm 36.39$ & $360.02 \pm 34.10$ & $362.45 \pm 12.45$ & $<0.001^{*}$ \\
\hline
\end{tabular}

$\mathrm{NO}_{x}$ denotes $\mathrm{NO}_{2}{ }^{-}$and $\mathrm{NO}_{3}{ }^{-}$collectively

${ }^{*} \mathrm{p}<0.05$ comparison between the three study groups (Kruskal-Wallis Test) 

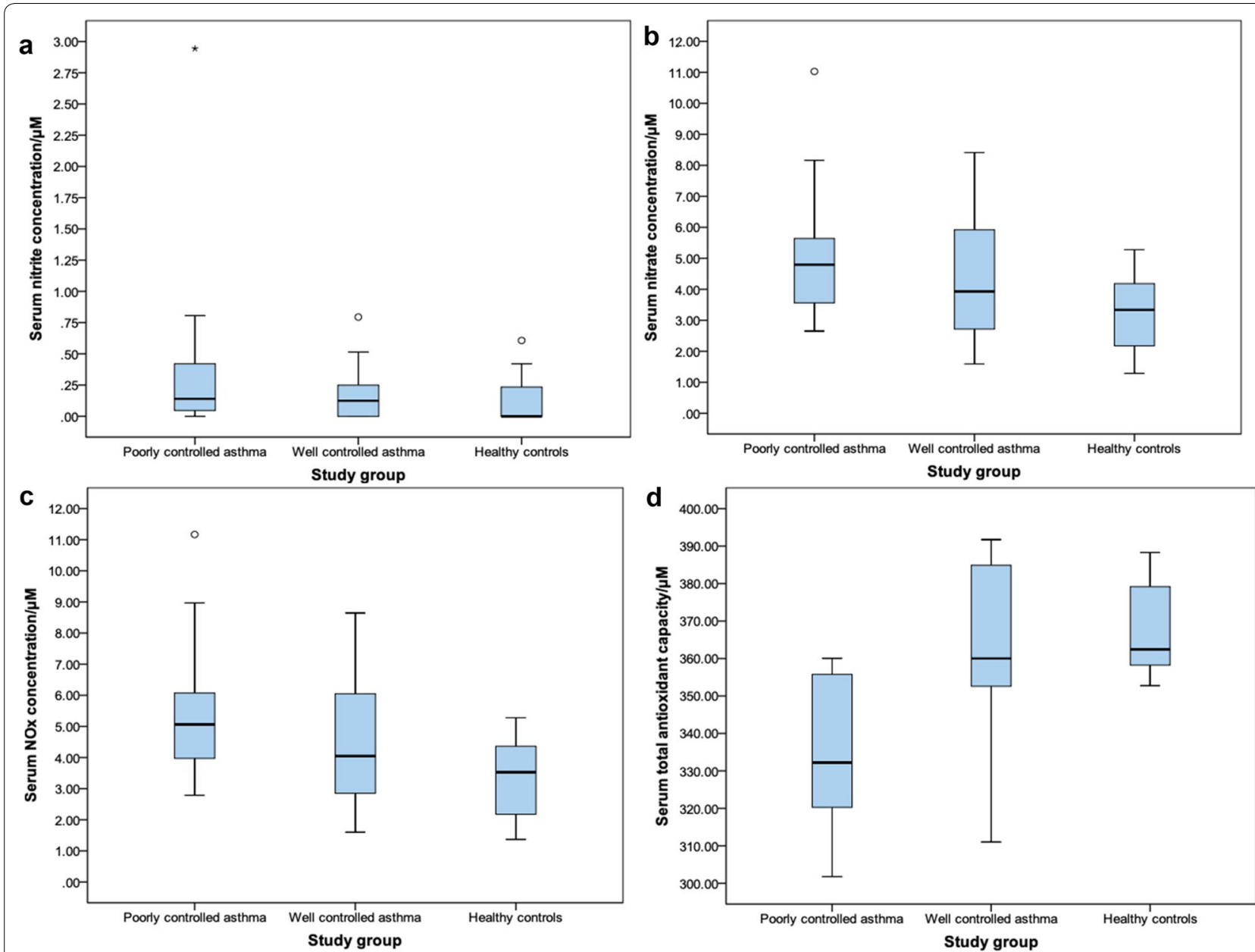

Fig. 1 Boxplots of serum concentrations of (a) nitrite, (b) nitrate and (c) $\mathrm{NO}_{x}$ and (d) serum TAOC

Table 4 Comparison of medians between the groups using the Mann-Whitney $U$ test

\begin{tabular}{|c|c|c|c|c|}
\hline & $\begin{array}{l}\text { Poorly controlled asthma } \\
(n=20)\end{array}$ & $\begin{array}{l}\text { Well controlled asthma } \\
(n=24)\end{array}$ & Healthy controls $(n=27)$ & $p$-value \\
\hline Serum nitrate concentration $/ \mu M$ & $4.79 \pm 2.15$ & $3.93 \pm 3.28$ & & 0.311 \\
\hline Serum $\mathrm{NO}_{x}$ concentration/ $\mu \mathrm{M}^{\mathrm{a}}$ & $5.06 \pm 2.31$ & $4.05 \pm 3.32$ & & 0.203 \\
\hline Serum nitrate concentration $/ \mu \mathrm{M}$ & & $3.93 \pm 3.28$ & $3.34 \pm 2.15$ & $0.036^{*}$ \\
\hline Serum $\mathrm{NO}_{x}$ concentration $/ \mu \mathrm{M}^{\mathrm{a}}$ & & $4.05 \pm 3.32$ & $3.53 \pm 2.35$ & $0.049^{*}$ \\
\hline Serum nitrate concentration $/ \mu \mathrm{M}$ & $4.79 \pm 2.15$ & & $3.34 \pm 2.15$ & $0.001^{*}$ \\
\hline Serum $\mathrm{NO}_{x}$ concentration/ $\mu \mathrm{M}^{\mathrm{a}}$ & $5.06 \pm 2.31$ & & $3.53 \pm 2.35$ & $<0.001^{*}$ \\
\hline Serum TAOC/ $\mu \mathrm{M}$ & $333.20 \pm 36.39$ & $360.02 \pm 34.10$ & & $0.003^{*}$ \\
\hline Serum TAOC/ $\mu \mathrm{M}$ & & $360.02 \pm 34.10$ & $362.45 \pm 12.45$ & 0.496 \\
\hline Serum TAOC/ $\mu \mathrm{M}$ & $333.20 \pm 36.39$ & & $362.45 \pm 12.45$ & $<0.001^{*}$ \\
\hline
\end{tabular}

a $\mathrm{NO}_{x}$ denotes $\mathrm{NO}_{2}{ }^{-}$and $\mathrm{NO}_{3}{ }^{-}$collectively

${ }^{*} \mathrm{p}<0.05$ comparison between the three study groups (Mann-Whitney $\mathrm{U}$ test) 

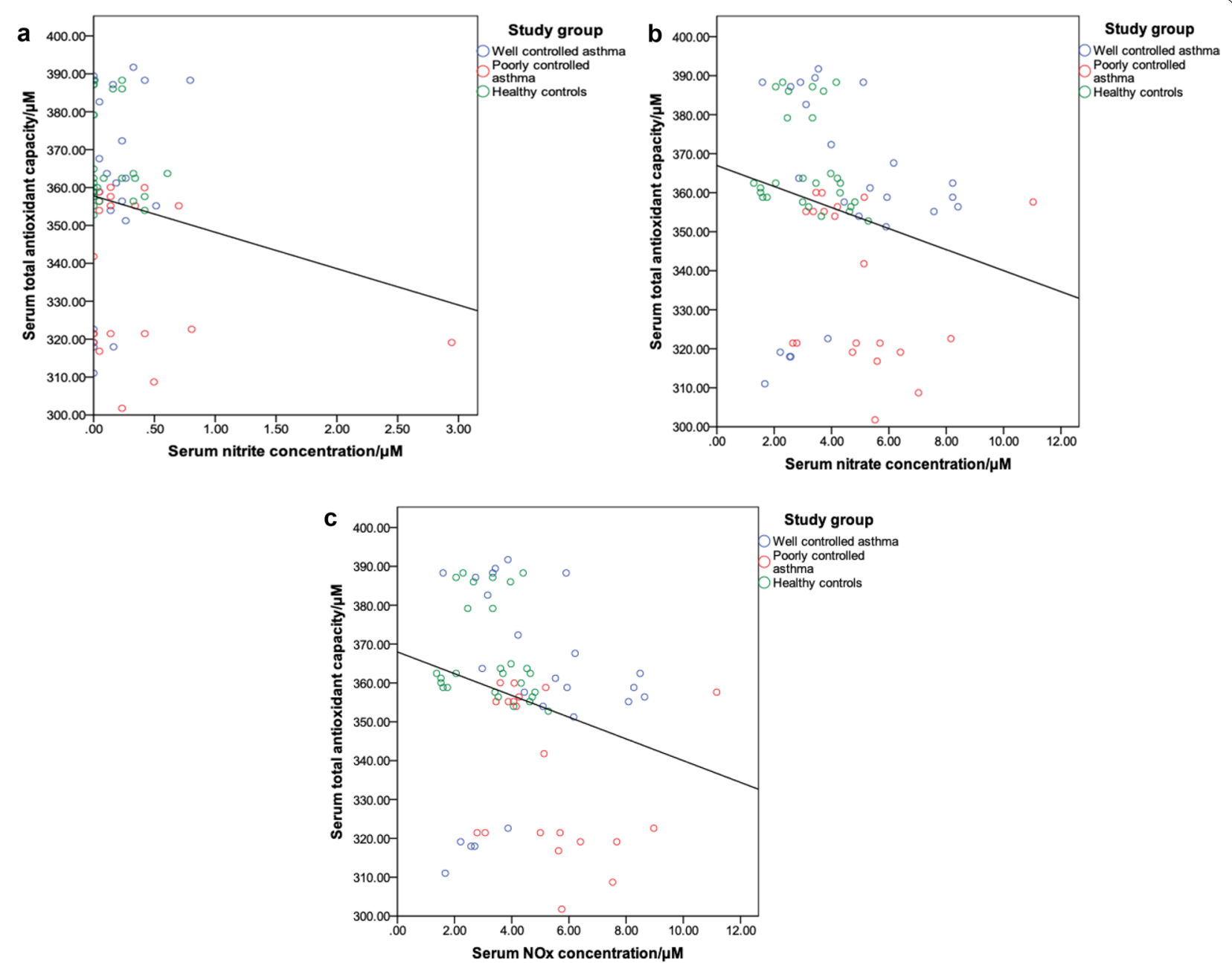

Fig. 2 Scatterplots for the correlation between serum TAOCs and (a) serum nitrite concentration $(r=-0.006, p=0.959)$, b serum nitrate concentration $(r=-0.306, p=0.010)$ and $(\mathbf{c})$ serum NOx concentration $(r=-0.312, p=0.008)$. The Spearman's correlations between the serum TAOC and the serum nitrate and NOx concentrations are statistically significant

the antioxidants in the serum may change due to the increased generation of the oxidants.

Using the Spearman correlation, significant negative correlations were shown only for the serum TAOCs between the serum nitrate $(\mathrm{r}=-0.306, \mathrm{p}=0.010)$ and $\mathrm{NO}_{\mathrm{x}}(\mathrm{r}=-0.312, \mathrm{p}=0.008)$ concentrations at the 0.01 level (Fig. 2).

\section{Discussion}

The present study is the first in Sri Lanka to measure the biomarkers of oxidative stress in patients with asthma. The results have clearly demonstrated that the concentrations of serum nitrate and $\mathrm{NO}_{\mathrm{x}}$, two biomarkers for oxidative stress, were significantly elevated in patients with asthma regardless of the level of disease control compared to healthy, non-asthmatic children. Conversely, serum TAOC was highest in healthy controls, and this was statistically significantly different from that of patients with poorly controlled asthma. There was no significant difference between healthy controls and wellcontrolled asthmatics with regard to serum TAOC.

Oxidative stress can be a manifestation of inflammation as well as an initiator of inflammation [36]. There are different biomarkers to assess the redox status of tissues including free radicals, lipid peroxidation products and alterations of antioxidant levels (as a surrogate marker). In this study serum nitrites, nitrates and TAOC were used as these assays have been used and validated for the local population previously for non-asthma related pathologies including leptospirosis [28, 35, 37], dengue haemorrhagic fever [34] and Parkinson disease [38]. Other studies which measured pro-oxidant levels in patients with asthma used exhaled nitric oxide (eNO) as this is a sensitive and specific marker of airway 
inflammation and a higher level of eNO was recorded in patients with asthma as compared to healthy controls [39-41]. However, routine measurements of eNO are quite costly to be implemented in the resource-limited settings of developing countries such as Sri Lanka, and in addition to that the molecule itself is volatile. Further, it is comparatively more difficult to measure the eNO levels in a paediatric population [42]. Using bronchoalveolar lavage as a source of secretions and airway cells would have been better but requires an invasive procedure, which can only be used in stable, well-controlled asthma. Another option is to assess the NO concentration in sputum but the levels may vary depending on whether the sputum is induced or not, and once again sputum is difficult to collect in children [43].

In this study, the approximate cost of carrying out serum NO levels was estimated at 3 CAD per sample. Thus the current study has demonstrated that measurement of serum NO may be a more cost-effective and practical approach in paediatric populations to demonstrate the occurrence of an underlying pathology in asthmatics as compared to a healthy population taking into consideration that measurement of eNO levels costs approximately 32 CAD per test $[44,45]$. The serum nitrite concentration did not show any significant differences across the study groups, while the serum nitrate concentration, which is obtained by subtracting nitrite concentration from NOx concentration, did show a statistically significant difference across the groups. Hence it can be argued that measurements of the serum NO concentrations with the modified Griess method alone may be adequate to differentiate oxidative stress between these groups. The difference in total NO concentration may manifest as a change in both nitrite and nitrate levels but since the latter anion is more stable, it is perhaps more accurately quantified than the nitrite level [46]. It is also known that approximately all of the nitrite in the systemic circulation is converted to nitrate by oxyhaemoglobulin during the L-arginine-NO pathway [47]. The total serum NO concentration was significantly higher in all asthmatics compared to healthy controls. This probably indicates the same intensity of inflammatory activity in airways of all asthmatics regardless of whether it is well controlled or not (there was no significant difference between well controlled and poorly controlled asthmatics).

On the contrary, as demonstrated in other studies [39, 48-50], the TAOC in this study was also significantly higher in well-controlled asthmatics and healthy children compared to poorly controlled asthmatics. Hence the antioxidant capacity may have a significant contribution to the clinical phenotype of "well controlled asthma" despite a same degree of oxidative stress. Furthermore, as antioxidants scavenge the surplus free radicals to reduce inflammation, the potential of antioxidants in the prevention and treatment of diseases has been studied in recent years [51]. Nadeem et al. [49], studied the oxidant- antioxidant imbalance in 38 patients with bronchial asthma and 23 control subjects in India. This study concluded that as a reduction in the antioxidant defenses (SOD enzyme) was associated with tissue damage in asthma, therapeutic augmentation of the antioxidant defences may be beneficial [49]. For example, in a NO-rich environment, SOD enzyme was shown to be less active leading to ROS and RNS generation $[25,52]$. The cumulative effect of SOD inactivation and oxidative stress led to apoptosis of airway cells, and perhaps contributed to airway hyperresponsiveness in asthma.

The beneficial effects of consuming an antioxidantrich diet have also been studied [52, 53]. One of these studies showed that a deficiency in vitamin $C$, which is the predominant antioxidant in the airway surface liquid, is associated with the elevated oxidative stress in asthma [52]. In addition, effective treatment of asthma may also help to build up the antioxidant reserves in asthmatics. Using antioxidants as therapeutics is a popular topic in academia and alternative treatment advocates. While the beneficial effects of such interventions were not tested, this study demonstrated that effective treatment for asthma itself could boost the antioxidant reserve in serum quite significantly compared to poorly controlled patients. As asthma therapy, which is managed in a step-manner, is well established, evidence-based, cheap and usually successful (provided that compliance and technique is good), this should be the primary and preferred method of asthma control over unproven methods such as dietary supplementation with antioxidants. This study has given an insight into the potential use of measurement of oxidative stress as an indicator of disease severity and, whether the use of antioxidants may be implemented as a therapeutic measure in disease management.

This study had some limitations. Even though healthy children with no apparent acute illness were selected, there is a possibility that the children suffered from some sort of acute illness in the recent past. The assays were done on serum biomarkers which may have been influenced by pathologies other than asthma (although the necessary precautions were taken to include children who had no other known co-morbidities at the time of recruitment for the study). The study assessed the plasma values of NO but as the primary pathophysiology is in the airway it would have been better to sample the airway NO levels. A study by Morris et al. [54], showed that eNO levels were significantly higher in asthma patients compared to healthy individuals although no significant 
difference was demonstrated for the $\mathrm{NO}$ metabolites in serum. Further studies will also be required to determine whether the higher differences in biomarkers is a by-product of on going inflammation due to asthma or whether the changes in the biomarkers actually contribute to the worsening of asthma (chicken and egg phenomenon). It is not clear whether the well-controlled asthmatics/healthy controls have improved antioxidant or whether increased antioxidants have improved the health status. Due to financial restrictions, the study was carried out during a specific time period (June to November 2019) thus the sample size was limited to the minimum number required to show an effect. The study participants were instructed to maintain an 8-h window between their last meal and sample collection due to the profound influence dietary nitrate can have on the plasma nitrite and nitrate levels; however, it cannot be certain that the participants adhered to the restriction.

\section{Conclusions}

As hypothesised, a significant increase in serum NOx concentration was observed in children with asthma (compared to healthy controls) regardless of whether the asthma is well controlled or not. Similarly, Healthy controls and those who had well-controlled asthma had significantly higher TAOC of serum compared to poorly controlled asthma patients.

It can be concluded that serum TAOC assessment has potential to be developed as a cheap, easy to perform assay to objectively confirm good asthma control. However, these findings need to be verified with a larger prospective study with accurate recording of clinical exacerbations (and not just by history taking) enabling control of multiple confounding factors.

\section{Abbreviations \\ ABTS: 2,2'-azinobis: (3-ethylbenzothiazoline-6-sulfonic acid); BMI: Body Mass Index; eNO: Exhaled Nitric Oxide; GINA: Global Initiative for Asthma; IBMBB: Institute of Molecular Biology, Biochemistry and Biotechnology; LKR: Sri Lankan Rupees; NO: Nitric oxide; $\mathrm{NO}_{x}$ : Nitric oxide metabolites; $\mathrm{NO}_{2}^{-}$: Nitrite; $\mathrm{NO}_{3}{ }^{-}$: Nitrate; PBS: Phosphate buffered saline; ROS: reactive oxygen species; RNS: Reactive nitrogen species; SOD: Superoxide dismutase; TAOC: Total antioxidant capacity; TEAC: Trolox equivalent antioxidant capacity; WHO; World Health Organisation.}

\section{Acknowledgements}

The authors thank the staff of Ward One and University Laboratory of the Lady Ridgeway Hospital. Technical assistance given by Dr. Narmada Fernando, Senior Lecturer in Cellular and Molecular Immunology at the IBMBB is gratefully acknowledged. We acknowledge the assistance given by Prof. Rajitha Wickremasinghe, Head of the Department and Professor of Public Health, Department of Community Medicine, Faculty of Medicine, Ragama for statistical assistance.

\section{Authors' contributions}

SH, PW, AK and YF planned the study and wrote the proposal. Patients were identified by PW and AK. Data and sample collection was carried out by YF and MA. Laboratory testing was carried out by YF and UD. Data analysis was done by YF, UD and MA. The first draft of the manuscript was written by YF, UD and MA. The final manuscript was written by PW, SH and AK. All authors read and approved the final manuscript.

\section{Funding}

Funding from the National Science Foundation, Sri Lanka is gratefully acknowledged.

\section{Availability of data and materials}

The data and material is available with the Principal Investigator.

\section{Ethics approval and consent to participate}

Ethical approval for the study was obtained from the Ethics Review

Committee, Faculty of Medicine, University of Colombo (EC-19-013).

\section{Consent for publication}

Verbal consent has been obtained from the parents of the children enrolled in the study to publish any significant findings. The study population has not been identified in any manner.

\section{Competing interests}

None declared.

\section{Author details}

${ }^{1}$ Institute of Biochemistry, Molecular Biology and Biotechnology, University of Colombo, Colombo, Sri Lanka. ${ }^{2}$ Colombo International School, Colombo 7 , Sri Lanka. ${ }^{3}$ Department of Paediatrics, Faculty of Medicine, University of Colombo, Colombo, Sri Lanka. ${ }^{4}$ Faculty of Medicine, University of Colombo, Colombo, Sri Lanka.

Received: 28 February 2020 Accepted: 10 July 2020

Published online: 22 July 2020

\section{References}

1. WHO. Bronchial asthma. Geneva: World Health Organisation; 2019. https ://www.who.int/en/news-room/fact-sheets/detail/asthma. Accessed 27 Sept 2019.

2. Huang WC, Fang LW, Liou CJ. Phloretin attenuates allergic airway inflammation and oxidative stress in asthmatic mice. Front Immunol. 2017;8:134.

3. Ministry of Health, Nutrition and Indigenous Medicine. Sri Lanka. http:// www.epid.gov.lk/web/images/pdf/wer/2018/vol_45_no_50-english.pdf. 2018. Accessed 24 Feb 2020.

4. Perera WAU, Jeewanthi HVR, Jayawardana KPDNS, Krishanthi MHTD, Dilsha RAN, Samarasekara PWGDP. Reasons for Recurrent Admission of Patients with Asthma in District General Hospital Embilipitiya. Proceedings of the 15th Open University Research Sessions. Sri Lanka; 2017.

5. Lee YC, Cheon KT, Lee HB, Kim W, Rhee YK, Kim DS. Gene polymorphisms of endothelial nitric oxide synthase and angiotensin-converting enzyme in patient with asthma. Allergy. 2000;55:959-63.

6. Aron Y, Busson M, Polla BS, Lockhart A, Swierczewski E, Favatier F. Analysis of hsp70 gene polymorphism in allergic asthma. Allergy. 1999;54:165-70.

7. McFadden JER. Asthma. In: Fauci AS, Braunwald E, Kasper DL, Hauser SL, Longo DL, Jameson JL, editors. Harrison's Principles of internal medicine. New York: McGrav-Hill; 2005. p. 1508-16.

8. Wright AL, Holberg CJ, Halonen M, Martinez FD, Morgan W, Taussig LM. Epidemiology of physician-diagnosed allergic rhinitis in childhood. Pediatrics. 1994:94:895-901.

9. Danansuriya MN, Rajapaksa LC, Weerasinghe A. Genetic, familial and environmental correlates of asthma among early adolescents in Sri Lanka: a case control study. World Allergy Organ J. 2015;8(1):1-7.

10. Smith TL. Asthma. New York: Infobase Publishing; 2009. p. 46.

11. Yang IV, Schwartz DA. Epigenetic mechanisms and the development of asthma. J Allergy Clin Immunol. 2012;130(6):1243-55.

12. Paramesh H. Epidemiology of asthma in India. Indian J Pediatr. 2002;69:309-12.

13. Seneviratne R, Gunawardena NS. Prevalence and associated factors of wheezing illnesses of children aged three to five years living in 
under-served settlements of the Colombo Municipal Council in Sri Lanka: a cross-sectional study. BMC Public Health. 2018;18(1):127.

14. Salam MT, Li YF, Langholz B, Gilliland FD. Early-life environmental risk factors for asthma: findings from the Children's Health Study. Environ Health Perspect. 2004;112:760-5.

15. Atmar RL, Guy E, Guntupalli KK, Zimmerman JL, Bandi VD, Baxter BD, Greenberg SB. Respiratory tract viral infections in inner-city asthmatic adults. Arch Int Med. 1998;158(22):2453-9.

16. de Freitas Carvalho MM, Lage NN, de Souza Paulino AH, Pereira RR, de Almeida LT, da Silva TF, de Brito Magalhães CL, de Lima WG, Silva ME, Pedrosa ML, da Costa Guerra JF. Effects of açai on oxidative stress, ER stress, and inflammation-related parameters in mice with high fat dietfed induced NAFLD. Sci Rep. 2019;9(1):8107.

17. Bentur L, Mansour Y, Brik R, Eizenberg Y, Nagler RM. Salivary oxidative stress in children during acute asthmatic attack and during remission. Respir Med. 2006;100(7):1195-201.

18. Fitzpatrick AM, Brown LAS, Holguin F, Teague WG, Program SAR, National Institutes of Health. Levels of nitric oxide oxidation products are increased in the epithelial lining fluid of children with persistent asthma. J Allergy Clin Immunol. 2009;124(5):990-6.

19. Valko M, Leibfritz D, Moncol J, Cronin MT, Mazur M, Telser J. Free radicals and antioxidants in normal physiological functions and human disease. Int J Biochem Cell Biol. 2007;39:44-84.

20. Goodyear-Bruch C, Pierce JD. Oxidative stress in critically ill patients. Am J Crit Care. 2002;11(6):543-51.

21. Jiang L, Diaz PT, Best TM, Stimpfl JN, He F, Zuo L. Molecular characterization of redox mechanisms in allergic asthma. Ann Allergy Asthma Immunol. 2014;113:137-42.

22. Harik-Khan Rl, Muller DC, Wise RA. Serum vitamin levels and the risk of asthma in children. Am J Epid. 2004;159:351-7.

23. Babusikova E, Jurecekova J, Evinova A, Jesenak M, Dobrota D. Oxidative damage and bronchial asthma. Respiratory diseases. Rijeka. London: InTech; 2012. p. 151-76.

24. Smith L, Shamsuddin M, Sporn PH, Denenberg M, Anderson J. Reduced superoxide dismutase in lung cells of patients with asthma. Free Radic Biol Med. 1997;22:1301-7.

25. Comhair SA, Xu W, Ghosh S, Thunnissen FB, Almasan A, Calhoun WJ, Janocha AJ, Zheng L, Hazen SL, Erzurum SC. Superoxide dismutase inactivation in pathophysiology of asthmatic airway remodeling and reactivity. Am J Path. 2005;166(3):663-74.

26. Li Y, Li G. Oxidative stress in asthma: a distinct clinical and pathologic feature? J Biol Regul Homeost Agents. 2016;30:1053-7.

27. Heyland DK, Dhaliwal R, Suchner U, Berger MM. Antioxidant nutrients: a systematic review of trace elements and vitamins in the critically ill patient. Intensive Care Med. 2005;31:327-37.

28. Kalugalage T, Rodrigo C, Vithanage T, Somaratne P, De Silva HJ, Handunnetti S, Rajapakse S. Low serum total nitrite and nitrate levels in severe leptospirosis. BMC Infect Dis. 2013;13(1):206.

29. Habermeyer M, Roth A, Guth S, Diel P, Engel KH, Epe B, Fürst P, Heinz V, Humpf HU, Joost HG. Nitrate and nitrite in the diet: how to assess their benefit and risk for human health. Mol Nutr Food Res. 2015;59:106-28.

30. Cardinale F, Tesse R, Fucilli C, Loffredo MS, lacoviello G, Chinellato I, Armenio L. Correlation between exhaled nitric oxide and dietary consumption of fats and antioxidants in children with asthma. J Allergy Clin Immunol. 2007;119:1268-70.

31. Savino A, Pelliccia P, Schiavone C, Primavera A, Tumini S, Mohn A, Chiarelli F. Serum and urinary nitrites and nitrates and Doppler sonography in children with diabetes. Diabetes Care. 2006;29:2676-81.

32. Balat A, Kilinç M, Cekmen MB, Güler E, Yürekli M, Sahinöz S, Coşkun Y. Adrenomedullin and total nitrite levels in children with acute rheumatic fever. Clin Biochem. 2005;38:526-30.

33. Hay FC, Westwood OMR. Phagocytosis, complement, and antibody dependent cytotoxicity. Practical immunology. 4th ed. Oxford: WileyBlackwell; 2002. p. 203-27.

34. Mapalagamage M, Handunnetti S, Premawansa G, Thillainathan S, Fernando T, Kanapathippillai K, Wickremasinghe R, De Silva AD, Premawansa S. Is total serum nitrite and nitrate (NOx) level in dengue patients a potential prognostic marker of dengue hemorrhagic fever? Dis Markers. 2018;2018:5328681.
35. Fernando N, Wickremesinghe S, Niloofa R, Rodrigo C, Karunanayake L, de Silva HJ, Wickremesinghe AR, Premawansa S, Rajapakse S, Handunnetti SM. Protein carbonyl as a biomarker of oxidative stress in severe leptospirosis, and its usefulness in differentiating leptospirosis from dengue infections. PLoS ONE. 2016;11(6):e0156085.

36. Pimková K, Chrastinová L, Suttnar J, Štikarová J, Kotlín R, Čermák J, Dyr JE. Plasma levels of aminothiols, nitrite, nitrate, and malondialdehyde in myelodysplastic syndromes in the context of clinical outcomes and as a consequence of iron overload. Oxid Med Cell Longev. 2014;2014:416028.

37. Gunaratna Rl, Handunnetti SM, Bulathsinghalage MRC, Somaratne P, Jayanaga A, de Silva HJ, Rajapakse S. Serum nitrite levels in Sri Lankan patients with leptospirosis. Asian Pac J Trop Med. 2012;5(1):75-8.

38. Rathnayake $D$, Chang T, Udagama P. Selected serum cytokines and nitric oxide as potential multi-marker biosignature panels for Parkinson disease of varying durations: a case-control study. BMC Neurol. 2019;19(1):56.

39. Ahmad A, Shameem M, Husain Q. Relation of oxidant-antioxidant imbalance with disease progression in patients with asthma. Ann Thorac Med. 2012;7(4):226-32.

40. Nandan D, Kansal P, Patharia N, Goyal P. Induced sputum nitrite levels correlate with clinical asthma parameters in children aged $7-18$ years with mild to moderate persistent asthma. J Lab Phys. 2012;8(2):90.

41. Chérot-Kornobis N, Hulo S, Edme J, de Broucker V, Matran R, Sobaszek A. Analysis of nitrogen oxides (NOX) in the exhaled breath condensate (EBC) of subjects with asthma as a complement to exhaled nitric oxide (FeNO) measurements: a cross-sectional study. BMC Res Notes. 2011;4:202.

42. Al-Ayed TM, Withington DE, Davis GM. Minimal exhaled nitric oxide production in the lower respiratory tract of healthy children aged 2 to 7 years. Ann Saudi Med. 2005;25(2):120-3.

43. Jang AS, Choi IS. Nitric oxide metabolites in patients with asthma: induced sputum versus blood. Respir Med. 1999;93(12):912-8.

44. Brooks EA, Massanari M. Cost-effectiveness analysis of monitoring fractional exhaled nitric oxide (FeNO) in the management of asthma. Manag Care. 2018;27(7):42-8.

45. Dick A, Wegner S, Wollensak T, Ernst C. Cost analysis of FeNO for asthma diagnosis in primary care in Germany. Eur Repir J. 2018;52:PA3151.

46. Wang Y, Townsend MK, Eliassen AH, Wu T. Stability and reproducibility of the measurement of plasma nitrate in large epidemiologic studies. N Am J Med Sci. 2013;6(2):82.

47. Groeneveld PH, Kwappenberg KM, Langermans JA, Nibbering PH, Curtis L. Relation between pro-and anti-inflammatory cytokines and the production of nitric oxide (NO) in severe sepsis. Cytokine. 1997:9(2):138-42.

48. Rahman I, Morrison D, Donaldson K, Macnee W. Systemic Oxidative stress in asthma, COPD and smokers. Am J Respir Crit Care Med. 1996;154:1055-60.

49. Nadeem A, Chhabra SK, Masood A, Raj HG. Increased oxidative stress and altered levels of antioxidants in asthma. J Allergy Clin Immunol. 2003;111(1):72-8.

50. Liao MF, Chen CC, Hsu MH. Evaluation of the serum antioxidant status in asthmatic children. Acta Paediatrica Taiwanica. 2004;45(4):213-7.

51. Li S, Chen G, Zhang C, Wu M, Wu S, Liu Q. Research progress of natural antioxidants in foods for the treatment of diseases. Food Sci Human Wellness. 2014:3:110-6.

52. Vural $H$, Uzun K. Serum and red blood cell antioxidant status in patients with bronchial asthma. Can Respir J. 2000;7(6):476-80.

53. Willers SM, Wijga AH, Brunekreef B, Scholtens S, Postma DS, Kerkhof M, de Jongste JC, Smit HA. Childhood diet and asthma and atopy at 8 years of age: the PIAMA birth cohort study. Eur Respir J. 2011;37(5):1060-7.

54. Morris CR, Poljakovic M, Lavrisha L, Machado L, Kuypers FA, Morris MS. Decreased arginine bioavailability and increased serum arginase activity in asthma. Am J Respir Crit Care Med. 2004;170:148-53.

\section{Publisher's Note}

Springer Nature remains neutral with regard to jurisdictional claims in published maps and institutional affiliations. 